\title{
Behavior of Concrete Containing Alternative Pozzolan Calcined Marl Blended Cement
}

\author{
Yasemin Akgün ${ }^{1 *}$ \\ 1 Department of Renewable Energy, Institute of Science, Ordu University, 52200 Altınordu, Ordu, Turkey \\ * Corresponding author, e-mail: yakgun@odu.edu.tr
}

Received: 15 October 2019, Accepted: 13 July 2020, Published online: 17 August 2020

\begin{abstract}
Natural marl which is calcined at appropriate temperature has potential being alternative pozzolan. Therefore, the calcined marl is wanted to be used as replacement material in blended cements with less clinker. This situation leads to improved performance of cement/concrete, reduced $\mathrm{CO}_{2}$ emissions, saving of energy. The properties of used pozzolan positively effect to some behavior of concrete. Shrinkage is one of these properties. The shrinkage of concrete is inherent property that needs to be control. Moreover, the shrinkage of concrete becomes even more important in some applications such as mass concrete, prestressed concrete. The aim of study is to determinate how will affected shrinkage of concrete containing alternative pozzolan calcined marl blended cements. Accordingly, the natural marl was calcined at $800^{\circ} \mathrm{C}$ for pozzolanic activation. The calcined marl was replaced with Portland cement at ratios of $0,10,30,50 \mathrm{wt} . \%$. The setting times, volume expansion, water demand, density, performance energy evaluation of blended cements were determined. The autogenous-drying shrinkage, mass loss and compressive strength tests were performed on concretes containing calcined marl blended cements. According to the results, pozzolanic activity of calcined marl and properties of blended cements containing calcined marl are comply with limit values of TS 25 and EN197-1. It was observed that autogenous-drying shrinkage and mass loss of concretes containing calcined marl blended cement were lower than that of concretes containing Portland cement. On the other hand, it was seen that compressive strength of concretes was increased up to $50 \%$ replacement ratio.
\end{abstract}

Keywords

autogenous-drying shrinkage, blended cement, calcined marl, concrete, pozzolan

\section{Introduction}

In generally, the construction industry is a key factor in the fight against energy saving and climate change. It accounted for $6 \%$ of final energy use and $11 \%$ of emissions (energy and process related) in recent studies. The cement production has an important share within this dispersion [1]. Cement which is the most widely used building material in the world will continue to be used increasingly in the future. The annual global cement production is projected to reach 3.7-4.4 billion tonnes by 2050 as specified by the World Business Council for Sustainable Development (WBCSD) [2-3] reports. It is known that cement is produced by calcination of clay and limestone at $1400-1500{ }^{\circ} \mathrm{C}$. At the end of this process, approximately $900 \mathrm{~kg}$ of $\mathrm{CO}_{2}$ is released per tonne of cement [4]. Therefore, cement productions are responsible for intensive energy consumption and $\mathrm{CO}_{2}$ emissions. The most effortless solution of this problem is to use of pozzolans which are added as replacement material to cement clinker at certain proportions. It means less energy consumption and less $\mathrm{CO}_{2}$ emissions due to the reduced amount of clinker. This can also lead to improve the performance of mortar/concrete containing pozzolan blended cement. In general, many natural and synthetic additives (such as volcanic tuff, diatomite, furnace slag, fly ash, silica fume) are used in blended cement. Depending on the increasing demand for cement in the future, additives in the market may not be able to meet the demand. Therefore, there is a need to alternative additive materials. Marl known as "clay contaminated with lime" is one of them.

As known, raw clays can be found in great abundance all around the world. And, they can be gained high pozzolanic activity by calcining at optimum temperatures between 600 and $800{ }^{\circ} \mathrm{C}$ [5-8]. Clays (most well-known is metakaolin) are an effective replacement material after calcination for 
blended cement production $[9,10]$. Moreover, there are also studies on the use of binary or ternary blended cements such as metakaolin-limestone [11-13], fly ash-limestone [1417]. The results of studies conducted on calcined clay blended cements and binary or ternary blended cements that contains synergic reactions are quite pleasing. Nature imitates man-made blended cements like natural marl. The natural marl is a form co-located of clay and limestone in nature. In fact, marl is known as a bad clay contaminated due to lime content. Therefore, it is not preferred in clay applications [7]. It has not pozzolanic activity before without calcined. But, if it is calcined at optimum temperature and if it is used with optimum replacement ratio, the natural marl is transformed into an effective potential as pozzolan in cement/concrete productions. After calcination process, it contains positive synergic components such as calcined clay and calcium. These synergic components positively effect to some behavior of final product concrete such as strength and durability. For example, the use of blended cement with less clinker reduces shrinkage that usually occurs in the cement paste matrix. It is known that shrinkage can change characteristics of concrete such as durability, stress distribution and deformation (crack formation). Therefore, shrinkage of concrete is the first questioned parameter in especially some applications such as high-performance concrete, repair concretes, mass concretes, prestressed concrete, shotcrete. The shrinkage negatively affects to the final performance of concrete. This inherent behavior of concrete should be kept under control. So, the using blended cements with less clinker by reducing the amount of cement is one of the most popular solutions to reduce shrinkage of concrete. Several studies have been conducted on shrinkage and performance of mortars/ concretes containing calcined clay blended cements. Some of them are given below.

Danner and Justnes [18] investigated the pozzolanic reactivity of two calcined natural clays as depend on burning temperature, residence time in the furnace, cooling conditions and particle size of the final product. They found that the calcination temperatures of highest pozzolanic reactivity for both clays are between 600 and $800{ }^{\circ} \mathrm{C}$. In this study, it was determined that while different cooling conditions had no identified effect on reactivity, decreased particle size and residence time increased the reactivity. Shi et al. [19] focused on sulfate resistance of calcined clay (CC)-limestone (L)-Portland cements for mortars exposed to a $0.11 \mathrm{M} \mathrm{Na}_{2} \mathrm{SO}_{4}$ solution at 5 and $20{ }^{\circ} \mathrm{C}$ after a hydration period of 91 days. As a result of study, they determined that all mortars with $\mathrm{CC} /(\mathrm{CC}+\mathrm{L}) \geq 0.5$ exhibit excellent sulfate resistance. Ferreiro et al. [20] examined workability and strength performance for blended cements with $35 \%$ mass replacement for two calcined clays and mixtures with limestone at different calcination temperatures $\left(850{ }^{\circ} \mathrm{C}-925{ }^{\circ} \mathrm{C}\right)$. Strength performance was maximized for finely ground raw clays calcined at temperatures up to $850{ }^{\circ} \mathrm{C}$. Workability was especially influenced by the calcined clay content and raw clay fineness, to a greater extent when calcined at low temperatures. Dhandapani et al. [21] described the potential of Limestone Calcined Clay Cement $\left(\mathrm{LC}^{3}\right)$ for use in structural concrete in comparison with Ordinary Portland Cement (OPC) and fly ash based blended cement (FA30). Mechanical properties such as compressive strength and elastic modulus and autogenous and drying shrinkage, along with various durability parameters of the different concretes were assessed. The results are indicated the superiority of $\mathrm{LC}^{3}$ binder over other binders in producing durable concrete. They stated that the major reason for the better performance was attributed to the more compact and denser microstructure of the system with the $\mathrm{LC}^{3}$ binder against OPC and FA30. It was seen from study that the drying shrinkage performance of concretes with all three binders is similar. Antoni et al. [11] showed that blended cements containing calcined clay and limestone exhibited a comparable mechanical performance with traditional Portland cement. They announced that abundance of calcined clay can meet to the needs of increasing demand for cement replacement materials. Justnes [22] specified that calcined marl is a new type of mineral additive that has the potential to be an alternative to high quality fly ash, metakaolin and silica fume. Akgün [23] determined that flexural-compressive strengths of mortars containing calcined marl blended cement at optimum temperature $\left(800{ }^{\circ} \mathrm{C}\right)$ is improved up to replacement ratio $50 \%$. Rakhimov et al. [24] stated that the Portland cement pastes enriched with calcined marl showed better physical-mechanical properties than those enriched with metakaolin. Soltani et al. [25] used calcined marl $(0,10,20 \%)$ and condensed silica fume $(0,7,10 \%)$ as replacement material with Portland cement. They said that marl needs a much lower calcination temperature $\left(750^{\circ} \mathrm{C}\right.$ ) than Portland cement (up to $1480^{\circ} \mathrm{C}$ ), contributes in prolonged pozzolanic reactions and represents characteristics of latent cement chemistry. However, they emphasized that the use of silica fume should be supported by calcined marl for long-term enhancement in mechanical strength and durability. Justness and Østnor [26] stated 
that calcined marl can replace for calcined clay, but then calcium carbonate content should be reduced in accordance with the remaining calcium carbonate content after calcined. Hu et al. [27] tested free drying shrinkage for ternary cementitious systems containing Portland cement, slag, fly ash. They announced that the free drying shrinkage increased with the increasing of slag content and reducing of the fly ash content. Rakhimova et al. [28] stated that the calcination of marl at $800{ }^{\circ} \mathrm{C}$ resulting in the formation of reactive $\mathrm{Si}, \mathrm{Al}$, and $\mathrm{Ca}$ due to the dehydroxylation of clay minerals and decarbonation of calcite makes marl suitable for use as a geopolymer precursor.

Although there are many studies on limestone and calcined clay systems in literature, there are very few studies on calcined marl blended cement. Moreover, there is no study on the shrinkage of calcined marl blended cement. Therefore, the aim of this study is to create scientific data for using with optimum values as an alternative pozzolan of natural marl in the cement industry and to determine how will affect shrinkage development of concretes containing calcined marl blended cement. For this purpose, the natural marl obtained from Sinop/Erfelek was calcined at calcination temperature $\left(800^{\circ} \mathrm{C}\right)$ decided by thermogravimetric (TGA) analysis. The physical, chemical, mineralogical properties and pozzolanic activity of marl were determined. The calcined marl was replaced with cement at ratios of 0, 10, 30 and $50 \mathrm{wt} . \%$. Some properties of blended cements such as setting times, water demand, volume expansion and density were determined. By considering that positive effects may be exhibited on shrinkage of calcined marl, the shrinkage behaviors, mass losses and compressive strengths of concrete samples containing calcined marl blended cements were examined. The test results were compared with each other and with Portland cement.

\section{Experimental design}

\subsection{Materials and methods}

The calcined marl used as replacement material in the study is a natural pozzolan from thermal treated clay group. The natural marl (M) was obtained from Sinop/ Erfelek region of Turkey. It was grinded from natural marl rock in a ball mill to provide approximately $80 \%$ passing value through $45 \mu \mathrm{m}$ sieve. In pozzolanic activity tests, CEN (The European Committee for Standardization) standard sand in accordance with EN 196-1 [29] was used. In lime-pozzolan mixtures, slaked lime $\left(\mathrm{Ca}(\mathrm{OH})_{2}\right)$ was used as specified in TS 25 [30]. The cement used in tests was CEM I 42.5 R type of Portland cement (PC) produced in accordance with EN 197-1 [31]. The PC was obtained from Unye Cement Company. In the concrete mixtures, the naturally formed aggregate with the maximum grain size of $16 \mathrm{~mm}$ was used. Aggregates used in this study are standard aggregates for concretes complying with EN 12620 [32]. Aggregates were provided from the Harşit valley, Giresun Province of Turkey. For all concrete samples, the water/ cement ratio was constant at 0.42 . It was used superplasticizer called "Reoplast 600" (at 2.0, 2.2, 2.4 and 2.6\% ratios) complying with EN 934-2 [33] by adding to mixture water in order to recover of adverse effect on concrete consistency of calcined marl in mixtures. In production of all samples, the water that does not contain organic substances, harmful minerals or salts was used.

The specific surface area (Blaine), density, chemical composition and mineralogical structure of materials used as pozzolan in blended cements have important effects on pozzolanic activity, strength, other properties. Therefore, these parameters were determined by methods given below. The amounts of marl used in mixtures were 0 (none), 10 (low), 30 (medium) and $50 \%$ (high) of cement weight. The natural marl was calcined at calcination temperature $\left(800{ }^{\circ} \mathrm{C}\right)$ decided by thermogravimetric (TGA) analysis. The density and specific surface (Blaine) of natural marl were determined according to EN 197-1 and [31] EN 196-6 [34], respectively. The chemical composition of natural marl was determined by X-ray fluorescence (XRF) analysis. This analysis was carried out by using desktop XRF (EDXRF) device as percentage (\%) with loss of ignition (LOI) amount on samples prepared as pellet in laboratory of "General Directorate of Mineral Research and Explorations". X-Ray Diffraction (XRD) analysis was performed to determine mineralogical composition of natural marl. This analysis was performed using a "Bruker D8 Advance" diffractometer (with $\mathrm{CuK} \alpha$-radiation and Ni filter) at $40 \mathrm{kV}$ and $40 \mathrm{~mA}$. The sample was scanned from $2 \theta$, 2 to $45^{\circ}$, at a scanning speed of $2 \% \mathrm{~min}$. The petrographic findings obtained from the rock of natural marl were determined under a polarization microscope in Black Sea Technical University, Mining Engineering Laboratory. The images for microstructure of natural marl and calcined marl were obtained using a Scanning Electron Microscope (SEM) that is brand of Hitachi, model of SU 1510 with EDX-(Energy Dispersive X-ray Spectroscopy) sensor in "Ordu University, Central Research Laboratory" coded as "ODUMARAL". For SEM investigations, it was made gold plating to provide conductivity on marl samples which have fineness used in the study. For this, the surface 
of sample on the carbon band of the gold plating device (sputter) was plated with gold at a thickness of approximately 10-20 nm with 20-30 mA. The ultrasonic pulse velocity (UPV) was determined for evaluating of the inner structure of cube $(150 \times 150 \times 150 \mathrm{~mm})$ concrete samples EN 13791 [35]. The all results obtained from the test series were compared amongst themselves and with each other.

\subsection{Tests of pozzolanic activity}

The pozzolanic activity can be defined as the ability of the active silica in pozzolan to react with water and $\mathrm{Ca}(\mathrm{OH})_{2}$. At the end of this reaction, strength increases due to new occurred calcium hydrate (CSH) gels [36]. The test for determination of pozzolanic activity of natural marl was made by mechanical test method which is determined with average compressive strength of lime-pozzolan mixture in accordance with TS25. The pozzolanic activity tests were performed on $40 \times 40 \times 160 \mathrm{~mm}$ prismatic samples. The molds of the prepared samples were covered with a glass plate to prevent evaporation. The samples could stand at room temperature $\left(23 \pm 2{ }^{\circ} \mathrm{C}\right)$ for 24 hours. And then, they were left for 6 days in a drying oven at $55 \pm 2{ }^{\circ} \mathrm{C}$ without removing the molds. The samples removed from the oven were left to cool until the room temperature reached. Finally, the compressive strengths of samples were performed in accordance with EN 196-1. The amounts of materials required to prepare three test samples for tests on pozzolanic activity are given in Table 1.

\subsection{Calcination of natural marl}

The clays which do not have pozzolanic activity become active after heating up to temperature interval $500-800^{\circ} \mathrm{C}$. The calcination temperature should be carefully selected according to the material used when it is desired to completely decomposition of original crystal structure in materials. Also, formation of thermodynamically more stable compounds such as tridimite-mullite occurred at the end of reacting with each other of silica and aluminum oxides should be prevented Because, this causes to little or no reaction against lime [37]. For this purpose,

Table 1 The amounts of materials for tests on pozzolanic activity

\begin{tabular}{lcc}
\hline Materials & Stated in TS25 & Composition \\
\hline $\mathrm{CaOH}_{2}(\mathrm{~g})$ & 150 & 150 \\
Standard sand $(\mathrm{g})$ & 1350 & 1350 \\
& $2 \times 150 \times($ density of pozzolan $/$ & 376.74 \\
Pozzolan $(\mathrm{g})$ & density of $\left.\mathrm{CaOH}_{2}\right)$ & \\
Water $(\mathrm{g})$ & $0.5 \times(150+$ pozzolan $)$ & 263.37 \\
\hline
\end{tabular}

if clay contain marl it should be calcined at least $800{ }^{\circ} \mathrm{C}$. Therefore, Thermo-Gravimetric Analysis (TGA) was performed to determine optimum calcination temperature of natural marl used in this study.

\subsection{Tests of blended cement}

The replacement ratios for blended cements containing calcined marl at $800{ }^{\circ} \mathrm{C}$ were $0,10,30$ and $50 \mathrm{wt} . \%$. So, the blended cements were obtained with labels M10, M30 and M50. The water demand, setting times and volume expansion tests of all cements were carried out in accordance with the EN 196-3 [38] by using Vicat and Le Chatelier test sets. The density and specific surface (Blaine) of blended cements containing calcined marl were determined according to EN 197-1 and EN 196-6, respectively.

\subsection{Compressive strength tests of concrete}

The concrete samples containing calcined marl blended cements were produced with labels CPC, CM10, CM30 and CM50. CPC label denotes concrete sample containing Portland Cement. CM10, CM30 and CM50 labels denotes concrete samples containing calcined marl. The concretes were prepared by applying the standard mixing, molding and curing procedures stated in EN 196-1 and EN 12390-2 [39]. The samples were prepared in laboratory environment where temperatures are $20 \pm 2{ }^{\circ} \mathrm{C}$ and relative humidity is $60 \pm 5 \%$. The absolute volume method given in ACI 211.1-91 [40] was used in mix design of concretes. The water-to-cement ratio of concrete samples is 0.42 . On the fresh concrete mixes, the slump test was performed according to EN 12350-2 [41]. The slumps of concretes are 6-7 cm. The compressive strength developments of concretes were carried out in accordance with the EN 12390-3 [42]. The compressive strengths of cube $(150 \times 150 \times 150 \mathrm{~mm})($ Fig. 1(a) $)$ concrete specimens were determined at 2, 14 and 28 days of age. The samples produced for development of compressive strength were removed from the molds after 24 hours and placed in the cure pool at $22 \pm 2{ }^{\circ} \mathrm{C}$ and kept until test age.

\subsection{Shrinkage tests of concrete}

In the shrinkage tests, single for autogenous shrinkage (Fig. 1(b)) and triple for drying shrinkage (Fig. 1(c)) prismatic molds made from stainless steel with internal surfaces coated by polyester film having $75 \times 75 \times 280 \mathrm{~mm}$ dimensions were used. The single molds used for autogenous shrinkage measurements have an anchoring pin on one side. In this way, the shrinkage is provided reading 
from a single side. A dial gauge that can made distance measurement and continuously recording with $\pm 12 \mathrm{~mm}$ stroke and with $0.001 \mathrm{~mm}$ accuracy is placed to the hole in the free side. This hole is closed with a thin polyester plate till the beginning of the initial set. The details of mold for autogenous shrinkage measurements are presented in Fig. 2. The views from the samples in the mold are given in Fig. 3. The procedure for drying shrinkage test is based on the ISO 1920-8 [43]. Both ends of the triple molds used for drying shrinkage measurements have measuring pins (gauge studs) due to it can made of readings in the vertical drying shrinkage apparatus. The drying shrinkage measuring apparatus used to determine the shrinkage strains of concretes is the length comparator as shown in Fig. 1(d). It is designed to accurately measure the height of concrete samples to within $\pm 0.1 \%$ of the total height. A digital indicator to an accuracy of within 0.0001 in. $(0.002 \mathrm{~mm})$ with 0 to 100 ( 0 to $25 \mathrm{~mm}$ ) total range is used. Five readings were taken for each specimen to minimize errors following the procedure mentioned in ISO 1920-8. As test results are significantly affected by the ambient temperature and humidity, production and measurements of samples are carried out

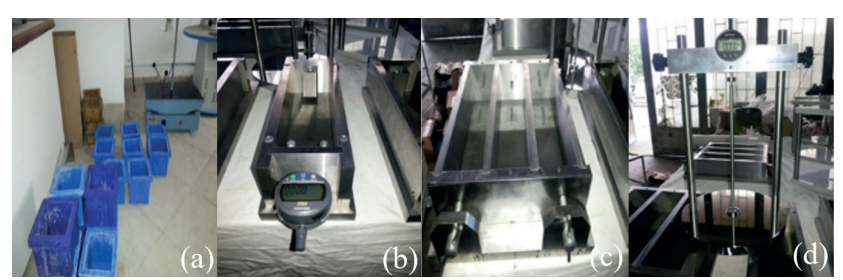

Fig. 1 The cubes (a), single (b) and triple (c) prismatic molds, vertical drying shrinkage apparatus (d)

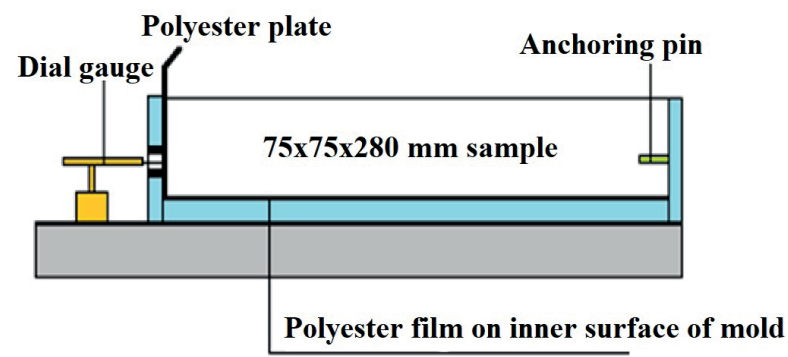

Fig. 2 The detail of mold for autogenous shrinkage measurements

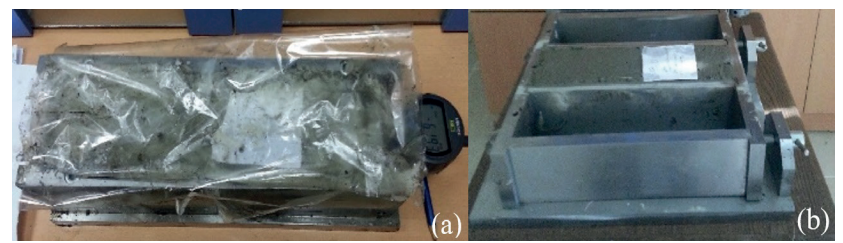

Fig. 3 The test samples for autogenous (a) and drying (b) shrinkage measurements in climatized drying room with a temperature of $23 \pm 2{ }^{\circ} \mathrm{C}$ and $50 \pm 4 \%$ relative humidity determined by ISO 1920-8. The samples produced for the autogenous shrinkage measurements were kept in the drying room as coated with polyester film. The samples produced for development of drying shrinkage were applied wet-sack cure for the first 7 days. The shrinkage tests were conducted according to ISO 1920-8. Also, the mass loss of the concrete was determined on same samples where were taken the length measurements of the samples produced for drying shrinkage.

\section{Results and discussions}

\subsection{Some properties of Portland cement, natural marl,} blended cements, aggregates

Some properties of natural marl (M), Portland Cement (PC), blended cements (M810, M830, M850) and aggregates are presented in Tables 2-6. The variations of specific surface-water demand and setting times-volume expansion for blended cements are given in Fig. 4 and Fig. 5, respectively.

Table 2 The properties of Portland cement (PC)

\begin{tabular}{|c|c|c|c|c|c|}
\hline \multirow{2}{*}{$\frac{\text { Chemical }}{\mathrm{SiO}_{2}}$} & \multirow{2}{*}{$\frac{(w t . \%)}{19.53}$} & \multicolumn{4}{|c|}{ Physical and mechanical properties } \\
\hline & & \multicolumn{3}{|c|}{ Density $\left(\mathrm{g} / \mathrm{cm}^{3}\right)$} & 3.12 \\
\hline $\mathrm{Al}_{2} \mathrm{O}_{3}$ & 5.33 & \multicolumn{3}{|c|}{ Specific surface (Blaine) $\left(\mathrm{cm}^{2} / \mathrm{g}\right)$} & 3210 \\
\hline $\mathrm{Fe}_{2} \mathrm{O}_{3}$ & 3.56 & Sieves $(\mu \mathrm{m})$ & 45 & 90 & 200 \\
\hline $\mathrm{CaO}$ & 62.26 & Over sieve (\%) & 32.89 & 12.15 & 2.73 \\
\hline $\mathrm{MgO}$ & 0.99 & Initial set (min) & 170 & & \\
\hline $\mathrm{SO}_{3}$ & 3.02 & Final set (min) & 255 & & \\
\hline $\mathrm{Na}_{2} \mathrm{O}$ & 0.95 & Vol. exp. (mm) & 2.00 & & \\
\hline $\mathrm{K}_{2} \mathrm{O}$ & 0.73 & Days & 2 & 7 & 28 \\
\hline $\begin{array}{l}\text { Loss of } \\
\text { ignition }\end{array}$ & 3.06 & $\begin{array}{c}\text { Compressive } \\
\text { strengths }(\mathrm{MPa})\end{array}$ & 32.30 & 44.60 & 53.00 \\
\hline \multirow{2}{*}{\multicolumn{2}{|c|}{$\begin{array}{l}\text { Clinker components } \\
(\%)\end{array}$}} & $\mathrm{C}_{3} \mathrm{~S}$ & $\mathrm{C}_{2} \mathrm{~S}$ & $\mathrm{C}_{3} \mathrm{~A}$ & $\mathrm{C}_{4} \mathrm{AF}$ \\
\hline & & 54.94 & 18.52 & 8.39 & 11.26 \\
\hline
\end{tabular}

Table 3 The properties of natural marl

\begin{tabular}{lccc}
\hline Chemical composition & (wt.\%) & \multicolumn{2}{c}{ Physical properties } \\
\hline $\mathrm{SiO}_{2}$ & 56.63 & Density, $\left(\mathrm{g} / \mathrm{cm}^{3}\right)$ & 2.70 \\
$\mathrm{Al}_{2} \mathrm{O}_{3}$ & 12.34 & Blaine $\left(\mathrm{cm}^{2} / \mathrm{g}\right)$ & 4630 \\
$\mathrm{Fe}_{2} \mathrm{O}_{3}$ & 7.46 & Over sieve $(\%)$ & \\
$\mathrm{CaO}$ & 12.91 & $45 \mu \mathrm{m}$ & 21.36 \\
$\mathrm{MgO}$ & 2.83 & $90 \mu \mathrm{m}$ & 7.80 \\
Loss of ignition & 7.03 & $200 \mu \mathrm{m}$ & 1.57 \\
\hline
\end{tabular}

Table 4 The properties of blended cements containing calcined marl

\begin{tabular}{lcccc}
\hline Physical properties & PC & M10 & M30 & M50 \\
\hline Specific surface $\left(\mathrm{cm}^{2} / \mathrm{g}\right)$ (Blaine) & 3210 & 3305 & 3610 & 3990 \\
Density $\left(\mathrm{g} / \mathrm{cm}^{3}\right)$ & 3.12 & 2.95 & 2.82 & 2.76 \\
\hline
\end{tabular}


Table 5 The water demand, setting times and volume expansion of cements

\begin{tabular}{lcccc}
\hline \multirow{2}{*}{ Cement } & \multicolumn{3}{c}{ Wetting times (min) } & Volume expansion \\
& & Initial & Final & $(\mathrm{mm})$ \\
\hline Limits EN 197-1 & - & $>0.75$ & $>1.25$ & $\leq 10$ \\
PC & 0.30 & 170 & 255 & 2.00 \\
M810 & 0.38 & 153 & 238 & 3.50 \\
M830 & 0.41 & 155 & 245 & 4.00 \\
M850 & 0.45 & 165 & 252 & 5.50 \\
\hline
\end{tabular}

Table 6 The densities and water absorption ratios of aggregates

\begin{tabular}{lcccc}
\hline Aggregates & $\begin{array}{c}\text { Dry } \\
\text { density } \\
\left(\mathrm{g} / \mathrm{cm}^{3}\right)\end{array}$ & $\begin{array}{c}\text { Saturated } \\
\text { density } \\
\left(\mathrm{g} / \mathrm{cm}^{3}\right)\end{array}$ & $\begin{array}{c}\text { Visible } \\
\text { density } \\
\left(\mathrm{g} / \mathrm{cm}^{3}\right)\end{array}$ & $\begin{array}{c}\text { Water } \\
\text { Absorption } \\
(\%)\end{array}$ \\
\hline Coarse $(\geq 4 \mathrm{~mm})$ & 2.50 & 2.55 & 2.65 & 1.20 \\
Fine $(\leq 4 \mathrm{~mm})$ & 2.55 & 2.60 & 2.69 & 1.96 \\
\hline
\end{tabular}

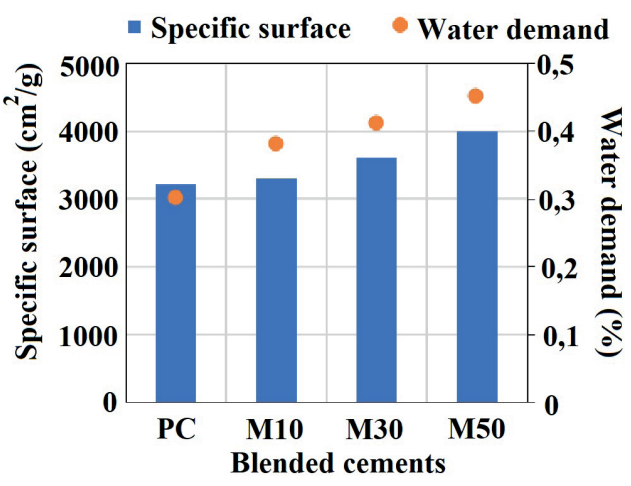

Fig. 4 The fineness and water demand of cements

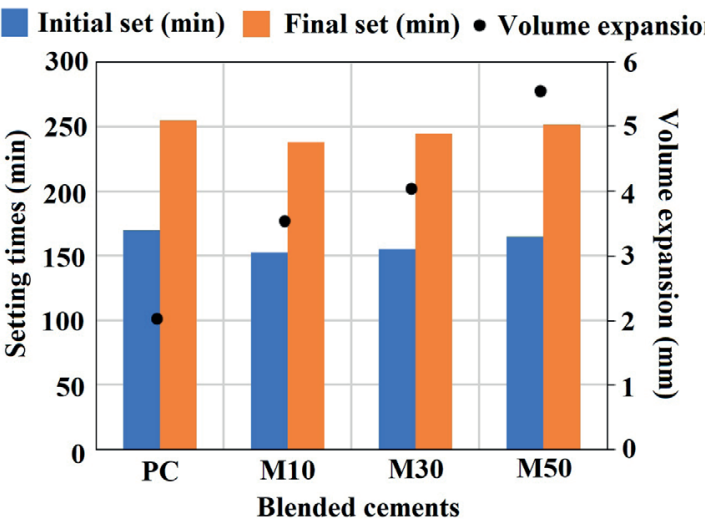

Fig. 5 The setting time and volume expansion of cements

The density of natural marl is $13.46 \%$ lower than PC. The specific surface area of natural marl is $44.24 \%$ higher than PC. This situation depends on mineral structure, porosity, fragility properties of natural marl. The cumulative passing (\%) of $45 \mu \mathrm{m}$ sieve for Portland cement and natural marl are $67.11 \%$ and $78.64 \%$, respectively. The densities of blended cements are decreased with increasing of calcined marl ratios. The specific surfaces of blended cements containing calcined marl are increased with increasing of calcined marl ratios. The water demands of blended cements containing calcined marl are increased as proportional with the replacement amount of calcined marl. Due to absorption by calcined marl of a part of the mixing water, the setting times in the blended cements containing calcined marl are slightly shorter than Portland cement. As calcined marl ratios increased, the volume expansion values increased. This changes that are an expected situation for pozzolan applications in cement are comply with the limit values in EN 197-1. The aggregates used in this study are standard aggregates for concretes complying with EN 12620.

\subsection{Mineralogical and petrographic structure}

The results obtained from mineralogical and petrographic analysis carried out on natural marl sample are given at below. The main binder of natural marl rock is calcite. Calcite $\left(\mathrm{CaCO}_{3}\right): 17 \%$. Quartz $\left(\mathrm{SiO}_{2}\right): 12 \%$. Feldspar $(\mathrm{K}, \mathrm{Na})\left(\mathrm{AlSi}_{3} \mathrm{O}_{8}\right): 4 \%$. Plagioclase $\mathrm{Na}\left(\mathrm{AlSi}_{3} \mathrm{O}_{8}\right)$ - $\mathrm{Ca}\left(\mathrm{Al}_{2} \mathrm{Si}_{2} \mathrm{O}_{8}\right)$, (these are the most common minerals in the rock): $46 \%$, Pyroxene $(\mathrm{Mg}, \mathrm{Fe}, \mathrm{Al})(\mathrm{Ca}, \mathrm{Na}) \mathrm{Si}_{2} \mathrm{O}_{6}$ : $12 \%$. Biotite $(\mathrm{Mg}, \mathrm{Fe}, \mathrm{Al}, \mathrm{Ti})_{2}\left(\mathrm{Si}_{6} \mathrm{Al}_{3} \mathrm{O}\right) 20(\mathrm{OH})_{4}: 2 \%$. Magnetite $\left(\mathrm{Fe}_{3} \mathrm{O}_{4}\right): 3 \%$. Foreign rock fragments (quartzite and basalt): (4\%). According to the findings of investigations performed on the samples used as additive in the study, the samples show natural marl characteristics.

\subsection{Pozzolanic activity of calcined marl}

Thermogravimetric Analysis (TGA) graph conducted for the determination of the optimum calcination temperature of the natural marl is given in Fig. 6. As seen, there is decomposition at most of the intact calcium carbonates in natural marl and calcination process results with uniform distribution of analysis curve. We can also see from TGA analysis graph that, calcium carbonate in natural marl decomposes at $800{ }^{\circ} \mathrm{C}$ as a function of partial pressure of $\mathrm{CO}_{2}$. The Scanning Electron Microscope (SEM) images and element spectra of natural marl (no calcination process) and calcined marls (calcination process at $600-800^{\circ} \mathrm{C}$ ) are given in Figs. 7-9. The fineness of sample for SEM investigation is $4630 \mathrm{~cm}^{2} / \mathrm{g}$ that is fineness used in the study. According to numerical data of element spectra determined with SEM, during the calcination, the amount of carbon element was obtained as $8.64 \mathrm{wt} . \%$ for natural marl, $8.02 \mathrm{wt} . \%$ for $600{ }^{\circ} \mathrm{C}$ and $0 \mathrm{wt} . \%$ for $800{ }^{\circ} \mathrm{C}$. These amounts mean that $\mathrm{CO}_{2}$ is completely removed after calcination process. 


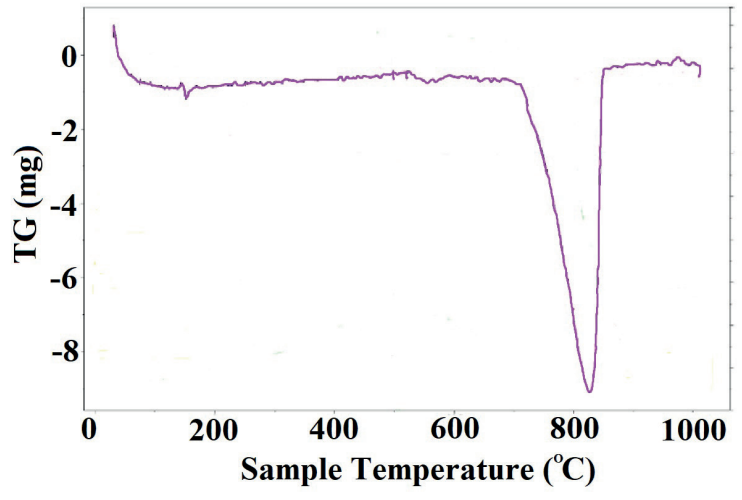

Fig. 6 The thermogravimetric analysis (TGA) graph of natural marl

Pozzolanic activity of calcined marl (at $800{ }^{\circ} \mathrm{C}$ ) are given in Table 7. According to Table 7, in TS 25, one of the eligibility criterions for pozzolans is the 7-days compressive strength of samples prepared with lime-natural pozzolan mixture. The limit value of the compressive strength
Table 7 The pozzolanic activity of calcined marl

\begin{tabular}{lcc}
\hline Conformity criterias & Limit values & Calcined marl \\
\hline $\begin{array}{l}\text { Lime-pozzolan mix. 7 days } \\
\text { compressive strength }(\mathrm{MPa})\end{array}$ & $>4$ & 8.10 \\
$\mathrm{SiO}_{2}+\mathrm{Al}_{2} \mathrm{O}_{3}+\mathrm{Fe}_{2} \mathrm{O}_{3}$ wt. $(\%)$ & $>70$ & 76.43 \\
Specific surface area $\left(\mathrm{cm}^{2} / \mathrm{g}\right)$ & $>3000$ & 4630 \\
\hline
\end{tabular}

is at least $4 \mathrm{MPa}$. In pozzolanic activity tests performed for natural marl and calcined marls at different temperatures, natural marl (no calcination) samples were broken without almost any loading in activity tests. The average compressive strength value for the lime-calcined marl mixture samples was determined as $3.80 \mathrm{MPa}$ for $600^{\circ} \mathrm{C}$. But it was $8.10 \mathrm{MPa}$ for $800{ }^{\circ} \mathrm{C}$. It has also been emphasized that the sum of $\mathrm{SiO}_{2}+\mathrm{Al}_{2} \mathrm{O}_{3}+\mathrm{Fe}_{2} \mathrm{O}_{3}$ in TS 25 should be at least $70 \%$ by mass. The value of this total was found to be $76.43 \%$ for natural marl. At the same time,

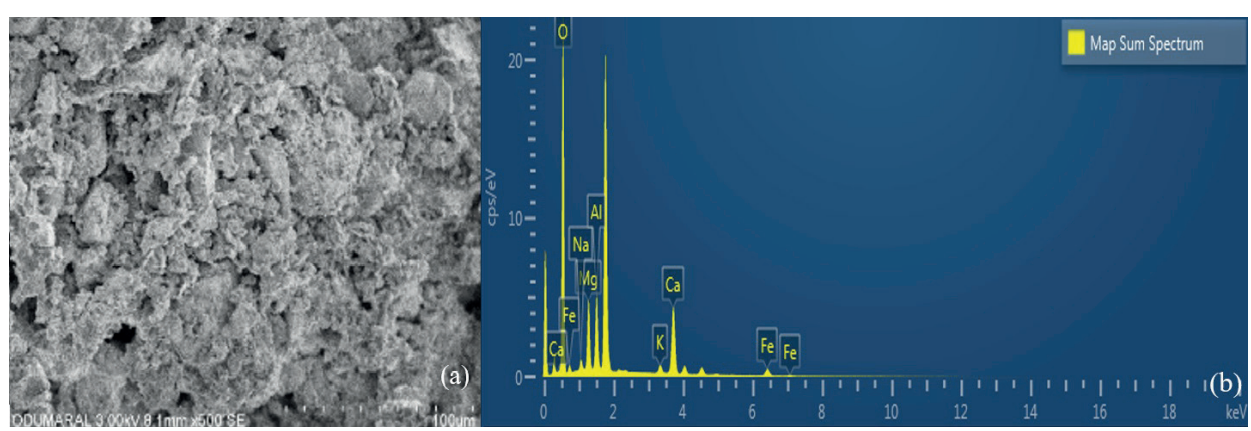

Fig. 7 SEM image (a) and element spectrum (b) of natural marl

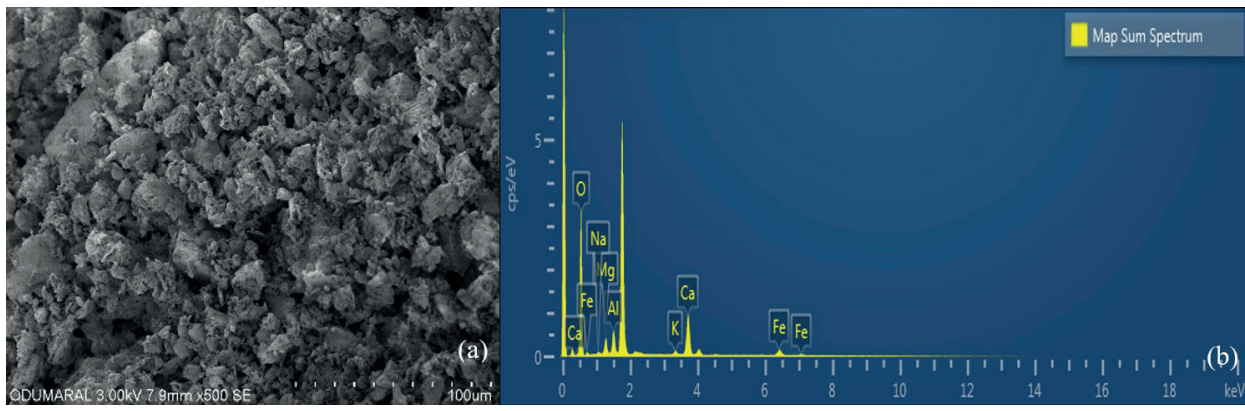

Fig. 8 SEM image (a) - element spectrum (b) of calcined marl at $600{ }^{\circ} \mathrm{C}$

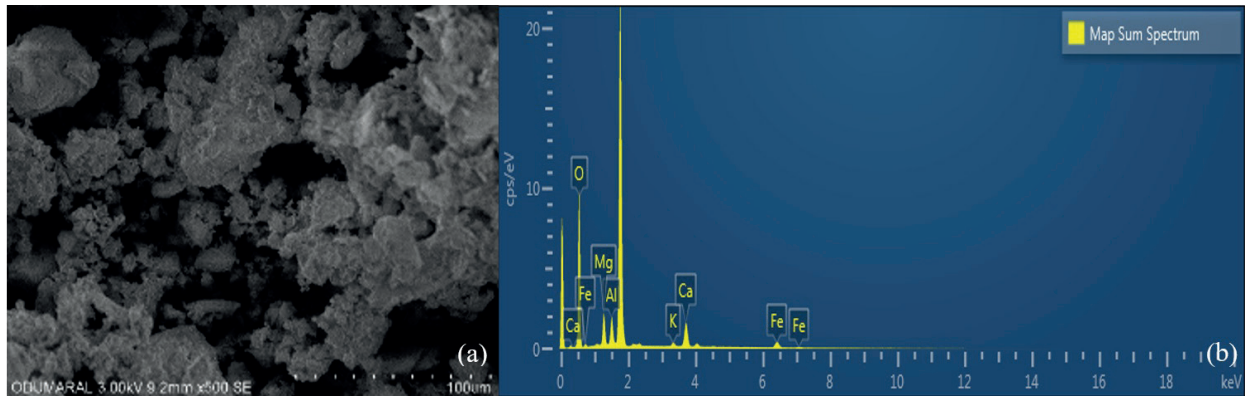

Fig. 9 SEM image (a) - element spectrum (b) of calcined marl at $800{ }^{\circ} \mathrm{C}$ 
the specific surfaces of the pozzolans should be greater than $3000 \mathrm{~cm}^{2} / \mathrm{g}$. The specific surface of pozzolan (calcined marl) which is used in this study was found to be $4630 \mathrm{~cm}^{2} / \mathrm{g}$.

It is thought that, since specific surface of natural marl is higher than that of Portland cement, pozzolan-lime reaction and activity value were increased in pozzolanic activity tests. The pozzolanic activity of calcined marl samples at $800^{\circ} \mathrm{C}$ was more than twice the desired level in TS 25 as an effect of calcination temperature, specific surface and $\mathrm{SiO}_{2}+\mathrm{Al}_{2} \mathrm{O}_{3}+\mathrm{Fe}_{2} \mathrm{O}_{3}$ content. This increasing can be explained by the decomposition of carbonates at $800{ }^{\circ} \mathrm{C}$. This decomposition starts at around $600{ }^{\circ} \mathrm{C}$ and arrives an optimum level at $800{ }^{\circ} \mathrm{C}$. The findings show that the calcined marl used in study has usability potential as a pozzolan.

\subsection{Compressive strength of concretes}

The mix design of concretes is given in Table 8. The compressive strength and density at 2, 14 and 28 days of concretes containing calcined marl blended cements are given in Table 9. The relations of fineness and density of cements/ concretes are given Fig. 10. The compressive strengths of concretes are given Fig. 11.

According to Fig. 11, compressive strengths of concretes containing calcined marl blended cement (CM10, CM30, CM50) are higher than that of concrete containing Portland cement (CPC). The density variations of blended concretes are similar with compressive strength variations. As seen, the compressive strength of concretes produced by calcined marl blended cements improved up to $50 \%$ replacement ratio because of calcination, mineralogical structure, relatively high silica-aluminate content and fineness. Even if the compressive strengths of concretes containing calcined marl blended cement slightly decrease at $50 \%$ replacement ratio, they still show values of structural concrete class all replacement ratios at both early and 28 days of age.

\subsection{Ultrasonic pulse velocity (UPV) of concretes}

The UPV values of concrete samples were determined for obtaining data about inner structure and comparing of strength test results. The UPV values are given in Table 10. The variation graph of UPVs is given in Fig. 12. It can be seen from the Fig. 13, the UPV values of concretes showed similar trends with compressive strengths of concretes. The UPV values decreased because of improved pore structure of concretes by increasing of calcined marl replacement ratio.
Table 8 Mix design of concretes

\begin{tabular}{|c|c|c|c|c|}
\hline Labels of concretes & $\mathrm{CPC}$ & CM10 & CM30 & CM50 \\
\hline Cement $\left(\mathrm{kg} / \mathrm{m}^{3}\right)$ & 343.00 & 295.72 & 218.33 & 147.62 \\
\hline Calcined marl $\left(\mathrm{kg} / \mathrm{m}^{3}\right)$ & - & 32.86 & 93.57 & 147.62 \\
\hline Mix water* $\left(\mathrm{kg} / \mathrm{m}^{3}\right)$ & 144.00 & 138.00 & 131.00 & 124.00 \\
\hline Saturated water $* *\left(\mathrm{~kg} / \mathrm{m}^{3}\right)$ & 16.43 & 16.63 & 16.84 & 17.05 \\
\hline Water/Cement & 0.42 & 0.42 & 0.42 & 0.42 \\
\hline Total aggregate $\left(\mathrm{kg} / \mathrm{m}^{3}\right)$ & 1825.51 & 1847.58 & 1870.73 & 1894.90 \\
\hline Plasticizier $\left(\mathrm{kg} / \mathrm{m}^{3}\right)$ & 6.86 & 7.23 & 7.49 & 7.68 \\
\hline
\end{tabular}

Table 9 The compressive strength and density of concretes

\begin{tabular}{cccccc}
\hline Concretes & Days & CPC & CM10 & CM30 & CM50 \\
\hline \multirow{2}{*}{ Density $\left(\mathrm{g} / \mathrm{cm}^{3}\right)$} & 2 & 2.47 & 2.62 & 2.69 & 2.55 \\
& 14 & 2.48 & 2.64 & 2.75 & 2.60 \\
& 28 & 2.50 & 2.75 & 2.78 & 2.70 \\
Compressive Strength & 2 & 42.28 & 46.14 & 49.30 & 44.13 \\
$(\mathrm{MPa})$ & 14 & 46.18 & 52.23 & 55.10 & 49.72 \\
& 28 & 51.26 & 59.60 & 60.50 & 56.98 \\
\hline
\end{tabular}

\section{Density of cement Density of concrete}

- Fineness of cement

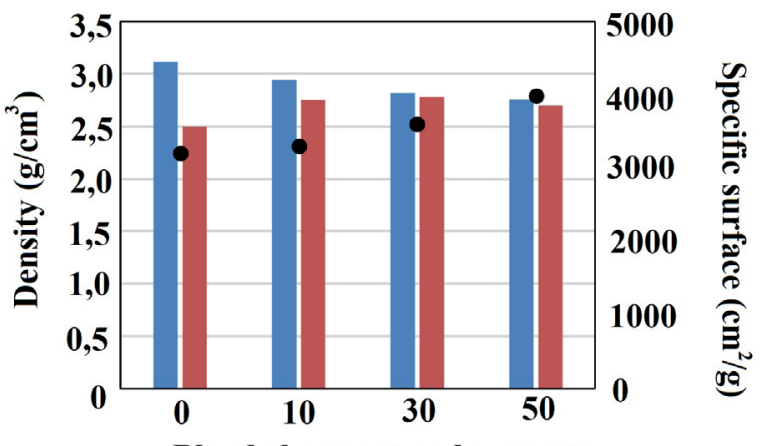

Blended cement and concrete

Fig. 10 The specific surface and density of cements/concretes $\square$ CPC CM10 CM30

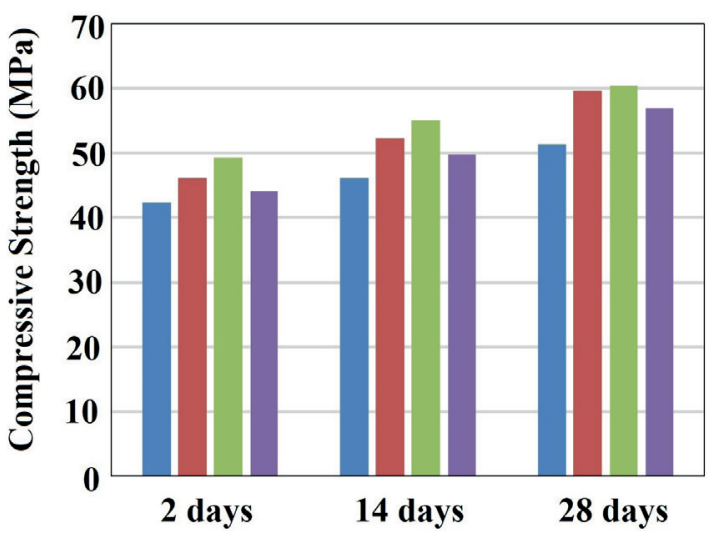

Fig. 11 The average compressive strength for concretes 
Table 10 Ultrasonic pulse velocity (UPV) for concretes

\begin{tabular}{lc}
\hline Concretes & Ultrasonic pulse velocity (UPV) (m/s) \\
\hline CPC & 4494 \\
CM10 & 4655 \\
CM30 & 4850 \\
CM50 & 4640 \\
\hline
\end{tabular}

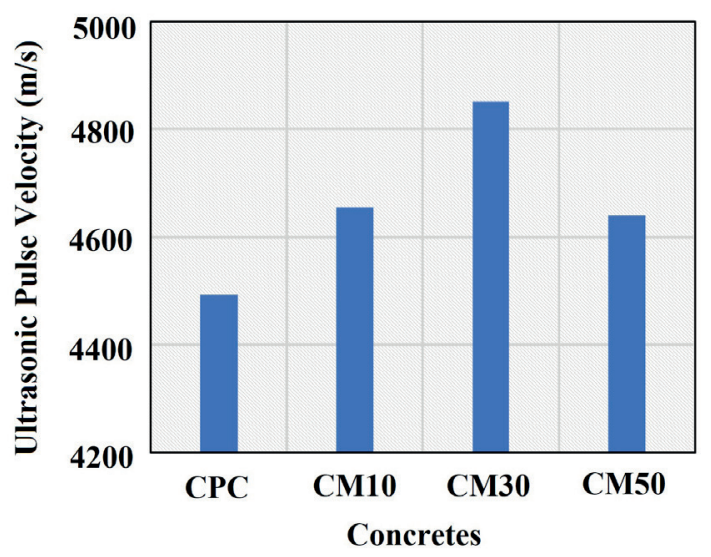

Fig. 12 The ultrasonic pulse velocity (UPV) for concretes

\subsection{The energy evaluations for blended cements}

The approximatively energy demand when pozzolan is used in blended cement has been evaluated in the literature [44-46]. According to these, the energy demand for the production of one ton of blended cement is calculated by using the Eq. (1) and Eq. (2), where $E$ is the energy demand (in $\mathrm{kWh} / \mathrm{t}$ ) for the production of one ton of blended cement, $C_{c}$ and $C_{p}$ are the proportions of cement and calcined marl (pozzolan) in the blended cement, respectively, $E_{\text {process cement }}$ and $E_{\text {grinding of cement }}$ are the energy consumption (in $\mathrm{kWh} / \mathrm{t}$ ) of the cement manufacturing process $(950 \mathrm{kWh} / \mathrm{t})$ and the finish grinding of the clinker $(50 \mathrm{kWh} / \mathrm{t})$, respectively, $E_{\text {calcination process of marl }}$ and $E_{\text {grinding of marl }}$ are the energy consumption (in $\mathrm{kW} \mathrm{h/t}$ ) for calcination at $800{ }^{\circ} \mathrm{C}$ of the natural marl $(500 \mathrm{kWh} / \mathrm{t})$ and the grinding of the natural marl due to approximately lower hardness with clinker $(45 \mathrm{kWh} / \mathrm{t})$, respectively, $E_{\text {performance }}$ is the energy consumption (in $\mathrm{kWh} / \mathrm{t} \cdot \mathrm{MPa}^{-1}$ ) for the production of one ton of blended cement, relative to the compressive strength of the concrete containing the blended cement considered, And finally, strength is the compressive strength of concrete containing composed $\left(C_{c}+C_{p}\right)$.

$$
\begin{aligned}
E & =C_{c}\left(E_{\text {process cement }}+E_{\text {grinding of cement }}\right) \\
& +C_{p}\left(E_{\text {calcination process of marl }}+E_{\text {grinding of marl }}\right)
\end{aligned}
$$

$E_{\text {performance }}=E /$ Strength

According to calculation results, the energy demands for one ton of cements and the performance energies for concretes are given in Figs. 13 and 14, respectively.

As seen, due to the much lower energy demand of calcination temperature and lower grinding energy, at all replacement ratios, the energy demands to produce one ton of blended cements containing calcined marl are lower than that of Portland cement. If the results considered relative to the performance of concrete, the performance energy decreases up to $50 \%$ replacement ratio with an acceptable strength value for concrete containing calcined marl. (values corresponding to 10,30 and $50 \%$ replacement ratios, respectively, the energy demands of blended cements are $4.55,13.65$ and $22.75 \%$ lower than that of Portland cement. the performance energies of concretes containing blended cements are 17.90, 26.82 and $30.46 \%$ lower than that of Portland cement) Thus, it is possible to say that to obtain an improvement as environmental and economical of natural marl blended cement productions.

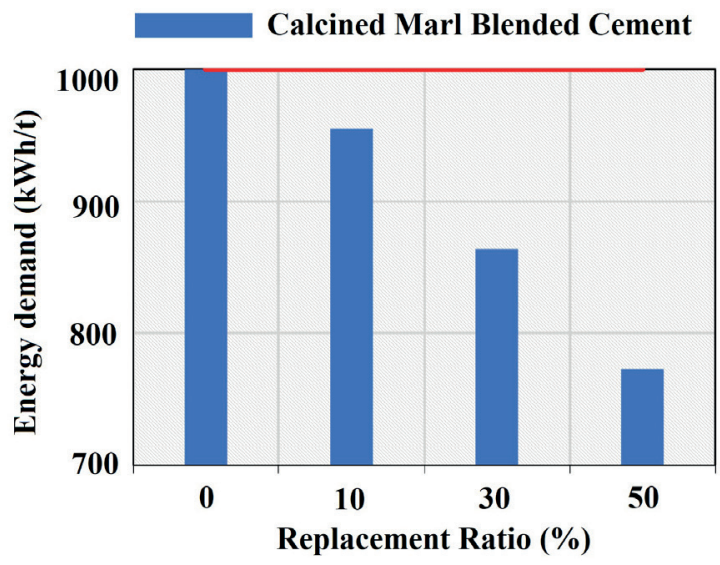

Fig. 13 The energy demand for one ton of cements

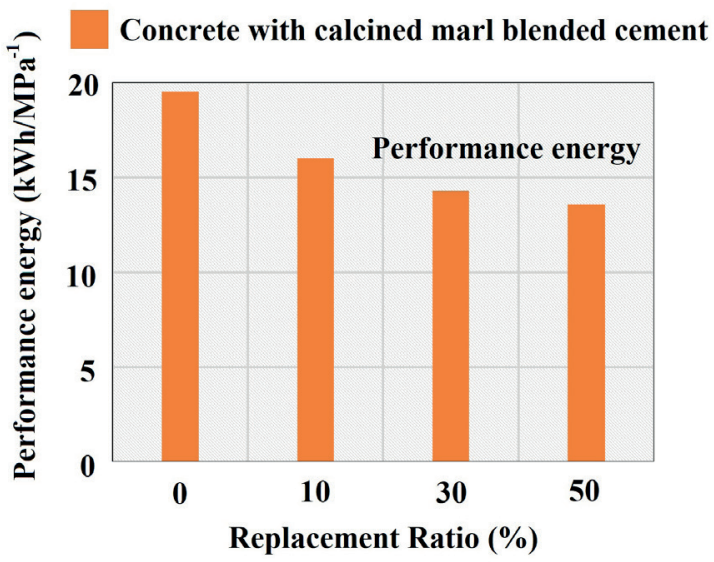

Fig. 14 The performance energy for concretes 


\subsection{Shrinkage development of concretes}

The variation graphs of autogenous and drying shrinkage are given in Fig. 15 and Fig. 16. The mass losses of concrete samples are shown in Table 11 and the mass loss-time graph is presented in Fig. 17.

It is seen from Fig. 15 that the autogenous shrinkage strains at 24 hours of concretes containing blended cements (CM10, CM30 and CM50) are approximately 10, 12.67 and $16 \%$ lower than that of concrete containing Portland cement, respectively. The reduction of autogenous shrinkage can be explained as both decreasing occurred at heat of hydration due to lower amount of clinker and increasing at water demand due to thinner marl. On the other hand, the marl has a thinner structure than Portland cement. So, the

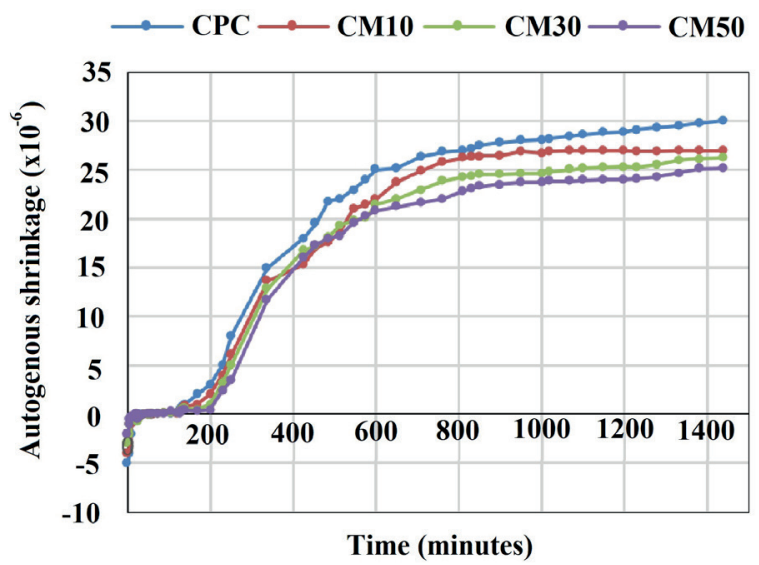

Fig. 15 The autogenous shrinkage strains-time variations of concretes

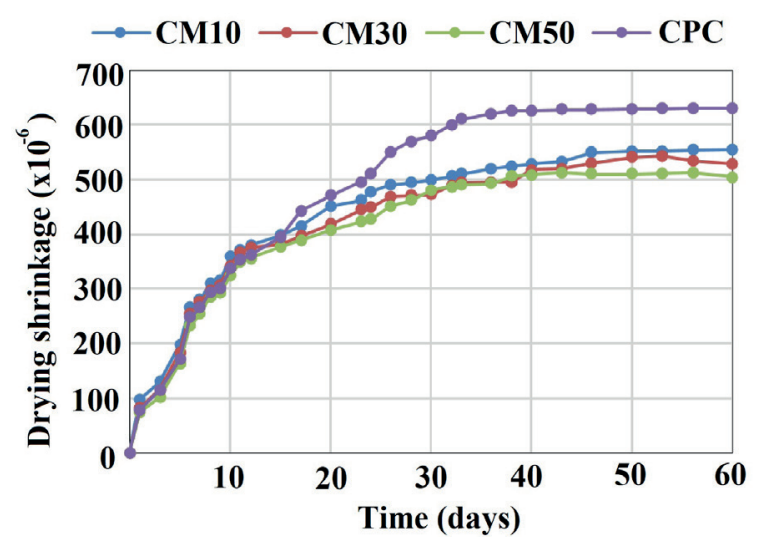

Fig. 16 The drying shrinkage strains-time variations of concretes

Table 11 The mass losses at drying shrinkage stage of concretes

\begin{tabular}{lcccc}
\hline & \multicolumn{4}{c}{ Mass losses of concrete samples (\%) } \\
Concretes & CPC & CM10 & CM30 & CM50 \\
\hline 2 days & 1.80 & 1.15 & 0.90 & 0.80 \\
14 days & 2.70 & 1.96 & 1.80 & 1.70 \\
28 days & 2.98 & 2.24 & 2.10 & 1.98 \\
60 days & 3.03 & 2.38 & 2.20 & 2.08 \\
\hline
\end{tabular}

shortening of the setting times of blended cements, the formation of new hydrate phases and the increasing trend in volumetric expansion are occurred. These phenomena support to the cited decreasing in the autogenous shrinkage.

It is seen from Fig. 16 that the drying shrinkage strains at 60 days of concretes containing blended cements (CM10, CM30 and CM50) are approximately 12, 16.17 and $19.93 \%$ lower than that of concrete containing Portland cement, respectively. In the evaluations made according to the replacement ratios, it is seen that drying shrinkage of concrete containing blended cement decreases with increasing in calcined marl content. The reason of decreasing of drying shrinkage can be explained as both the pozzolanic reactions of marl and slower-less evaporation of water in concrete samples with low porosity due to micro-filler effect of marl. It can also be said that the use of marl increases the water demand due to its high specific surface area and consumes a significant amount of the free water when it is hydrated. This contributes to a decrease in drying shrinkage. These results support the previous findings that shrinkage of concrete with pozzolan is lower than that of concrete without pozzolan [47-49].

The mass losses of the concretes were determined on same samples where were taken the length measurements of the samples produced for drying shrinkage. As known, it is difficult to distinguish between the two types of shrinkage. Although both shrinkages occur from moisture loss, the difference between them is that water evaporates to outside in the drying shrinkage. But, in the autogenous shrinkage, the water is consumed inside [50]. So, there is no mass loss in the sample at the stage where the autogenous shrinkage occurs.

As seen from Fig. 17, in the evaluations made according to replacement ratios, the mass loss of the concrete sample decreases with increasing of calcined marl content. On

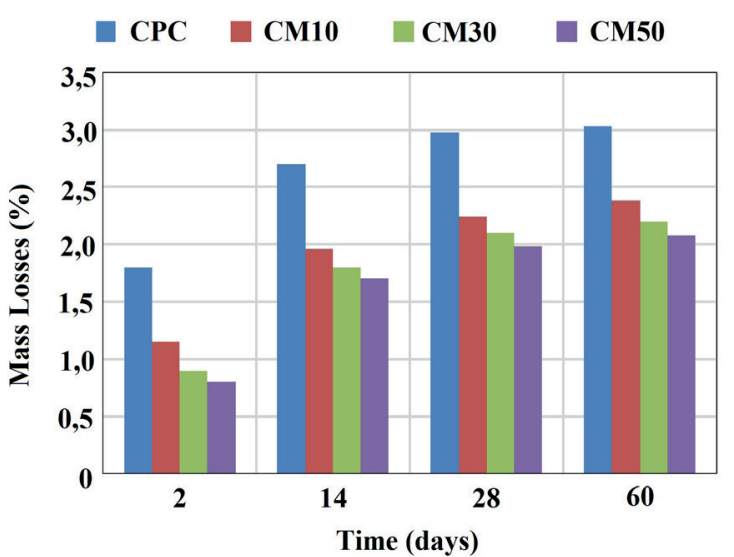

Fig. 17 The mass loss-time variations of concretes 
the other hand, in the evaluations made between blended cements and Portland cement, the mass losses at the 60 days of the concretes containing blended cements (CM10, CM30 and CM50) are approximately 21.45, 27.39 and 31.35 $\%$ lower than that of concrete containing Portland cement, respectively. The reason of that is evaporation of water into the external environment during drying shrinkage.

These reductions in autogenous-drying shrinkage and mass loss will positively contribute to management of internal stress distribution in concrete and to crack formation occurred due to shrinkage of concrete.

\section{Conclusions}

The pozzolanic activity determined by mechanical test method of calcined marl is $8.10 \mathrm{MPa}$. The calcined marl investigated in the study has usability potential as pozzolan for sustainable blended cement/concrete productions due to its properties such as high silica-alumina content, mineralogical structure and pozzolanic activity. The densities of blended cements/concretes slightly decreased with increasing of replacement ratio due to the low density of calcined marl. Blaine values and water demands of blended cements containing marl increased with increasing of replacement ratios. The setting times of blended cements containing calcined marl are slightly shorter than that of Portland cement. These values of blended cements are complied

\section{References}

[1] Abergel, T., Dean, B., Dulac, J., Hamilton, I. "2018 Global Status Report, Towards a zero-emission, efficient and resilient buildings and construction sector", IEA, Paris, France, 2018. [online] Available at: https://www.iea.org/reports/2018-global-status-report

[2] CSI "Cement Industry Energy and $\mathrm{CO}_{2}$ Performance "Getting the numbers right"", The Cement Sustainability Initiative, Geneva, Switzerland, 2009. [online] Available at: https://www.wbcsd. org/Sector-Projects/Cement-Sustainability-Initiative/Resources/ Getting-the-Numbers-Right

[3] Benhelal, E., Zahedi, G., Shamsaei, E., Bahadori, A. "Global strategies and potentials to curb $\left(\mathrm{CO}_{2}\right)$ emissions in cement industry", Journal of Cleaner Production, 51, pp. 142-161, 2013.

https://doi.org/10.1016/j.jclepro.2012.10.049

[4] Hasanbeigi, A., Price, L., Lu, H., Lan, W. "Analysis of energy-efficiency opportunities for the cement industry in Shandong Province, China: A case study of 16 cement plants", Energy, 35(8), pp. 3461$3473,2010$.

https://doi.org/10.1016/j.energy.2010.04.046

[5] Fernandez, R., Martirena, F., Scrivener, K. L. "The origin of the pozzolanic activity of calcined clay minerals: A comparison between kaolinite, illite and montmorillonite", Cement and Concrete Research, 41(1), pp. 113-122, 2011.

https://doi.org/10.1016/j.cemconres.2010.09.013 with the limit values in EN 197-1. The energy demand for producing one ton of blended cements containing calcined marl is lower than that of Portland cement due to the low calcination temperature and low grinding energy of natural marl. Similarly, the performance energies relative to strength of concretes containing calcined marl blended cement are reduced at all replacement ratios. The compressive strengths of concretes containing calcined marl blended cements improved up to $50 \%$ replacement ratio. According to this, the calcined marl is an alternative pozzolan additive that increases the ultimate strength when is used as blended cement in the cementitious systems. The shrinkage strains and mass losses of concretes containing calcined marl blended cements were lower than that of concretes containing Portland cement. It is thought that calcined marl blended cement is a suitable alternative pozzolan for non-shrinkage mortar/concrete manufacturing thanks to its use with optimum values. According to all these results, it is possible to say that calcined marl blended cement productions are pleasing in terms of environmental, economic and performance based concrete design.

\section{Acknowledgement}

This study was funded by the Scientific Research Project Unit of Ordu University under Project No: AR-1366. We would like to thanks to Votorantim Cement Company.

[6] Yanguatin, H., Ramírez, J. H., Tironi, A., Tobón, J. I. "Effect of thermal treatment on pozzolanic activity of excavated waste clays", Construction and Building Materials, 211, pp. 814-823, 2019. https://doi.org/10.1016/j.conbuildmat.2019.03.300

[7] Danner, T., Østnor, T., Justnes, H. "Calcined Marl as Pozzolan for Sustainable Development of the Cement and Concrete Industry", In: 12th CANMET/ACI International Conference on Recent Advances in Concrete Technology and Sustainability Issues, Prague, Czech Republic, 2012, pp. 357-365. [online] Available at: https:/www. researchgate.net/publication/259005747_Calcined_Marl_as _ Pozzolana_for_Sustainable_Development_of_the_Cement_and_ Concrete_Industry

[8] $\mathrm{Ng}$, S., Justnes, H. "Influence of dispersing agents on the rheology and early heat of hydration of blended cements with high loading of calcined marl", Cement and Concrete Composites, 60, pp. 123-134, 2015.

https://doi.org/10.1016/j.cemconcomp.2015.04.007

[9] Mikhailenko, P., Cassagnabère, F., Emam, A., Lachemi, M. "Influence of physico-chemical characteristics on the carbonation of cement paste at high replacement rates of metakaolin", Construction and Building Materials, 158, pp. 164-172, 2018.

https://doi.org/10.1016/j.conbuildmat.2017.10.021 
[10] da Silva Andrade, D., da Silva Rêgo, J. H., Morais, P. C., Rojas, M. F. "Chemical and mechanical characterization of ternary cement pastes containing metakaolin and nanosilica", Construction and Building Materials, 159, pp. 18-26, 2018. https://doi.org/10.1016/j.conbuildmat.2017.10.123

[11] Antoni, M., Rossen, J., Martirena, F., Scrivener, K. "Cement substitution by a combination of metakaoline and limestone", Cement and Concrete Research, 42(12), pp. 1579-1589, 2012. https://doi.org/10.1016/j.cemconres.2012.09.006

[12] Rui, K., Hongxing, W., Yunzhi, T., Lehua, W. "Solidification of High Organic Matter Content Sludge by Cement, Lime and Metakaolin", Periodica Polytechnica Civil Engineering, 63(1), pp. 53-62, 2019. https://doi.org/10.3311/PPci.12293

[13] Sánchez, M. A., Molina, W. M., García, H. L. C., Guzmán, E. M. A., Acosta, A. A. T., Ortega, J. M. P. "Properties of Portland Cement Mortar with Substitutions of Natural and Expanded Perlite", Periodica Polytechnica Civil Engineering, 62(2), pp. 508-516, 2018. https://doi.org/10.3311/PPci.11411

[14] De Weerdt, K., Justnes, H. "Synergic reactions in triple blended cements", In: 11th NCB International Seminar on Cement and Building Materials, New Delhi, India, 2009, pp. 257-261.

[15] De Weerdt, K., Justnes, H., Kjellsen, K. O., Sellevold, E. "Fly ashlimestone ternary composite cements: synergy effect at 28 days", Nordic Concrete Research, 42(2), pp. 51-70, 2010. [online] Available: https://nordicconcrete.net/wp-content/uploads/2010/02/ NCR-nr.-42.pdf

[16] De Weerdt, K., Kjellsen, K. O., Sellevold, E., Justnes, H. "Synergy between fly ash and limestone powder in ternary cements", Cement and Concrete Composites, 33(1), pp. 30-38, 2011. https://doi.org/10.1016/j.cemconcomp.2010.09.006

[17] De Weerdt, K. Ben Haha, M., Le Saout, G., Kjellsen, K. O., Justnes, H., Lothenbach, B. "Hydration mechanism of ternary Portland cements containing limestone powder and fly ash", Cement and Concrete Research, 41(3), pp. 279-291, 2011. https://doi.org/10.1016/j.cemconres.2010.11.014

[18] Danner, T., Justnes, H. "The Influence of Production Parameters on Pozzolanic Reactivity of Calcined Clays", Nordic Concrete Research, 59(2), pp. 1-12, 2018. https://doi.org/10.2478/ncr-2018-0011

[19] Shi, Z., Ferreiro, S., Lothenbach, B., Geikerd, M. R., Kunther, W., Kaufmann, J., Herfort, D., Skibsted, J. "Sulfate resistance of calcined clay - limestone - Portland cements", Cement and Concrete Research, 116, pp. 238-251, 2019.

https://doi.org/10.1016/j.cemconres.2018.11.003

[20] Ferreiro, S., Canut, M. M. C., Lund, J., Herfort, D. "Influence of fineness of raw clay and calcination temperature on the performance of calcined clay-limestone blended cements", Applied Clay Science, 169, pp. 81-90, 2019.

https://doi.org/10.1016/j.clay.2018.12.021

[21] Dhandapani, Y., Sakthivel, T., Santhanam, M., Gettu, R., Pillai, R. G. "Mechanical properties and durability performance of concretes with Limestone Calcined Clay Cement (LC $\left.{ }^{3}\right)$ ", Cement and Concrete Research, 107, pp. 136-151, 2018. https://doi.org/10.1016/j.cemconres.2018.02.005
[22] Justnes, H. "How to Make Concrete More Sustainable", Journal of Advanced Concrete Technology, 13(3), pp. 147-154, 2015. https://doi.org/10.3151/jact.13.147

[23] Akgün, Y. "Alternatif puzolan kalsine marn içeren sürdürülebilir katk1lı çimentolar (Sustainable blended cements containing alternative pozzolan calcined marl)", Dicle Üniversitesi Mühendislik Fakültesi Mühendislik Dergisi, 10(2), pp. 779-789, 2019. (in Turkish) https://doi.org/10.24012/dumf.492137

[24] Rakhimov, R. Z., Rakhimova, N. R., Gaifullin, A. R., Morozov, V. P. "Properties of Portland cement pastes enriched with addition of calcined marl", Journal of Building Engineering, 11, pp. 30-36, 2017. https://doi.org/10.1016/j.jobe.2017.03.007

[25] Soltani, A., Tarighat, A., Varmazyari, M. "Calcined Marl and Condensed Silica Fume as Partial Replacementfor Ordinary Portland Cement", International Journal of Civil Engineering, 16, pp. 1549-1559, 2018. https://doi.org/10.1007/s40999-018-0289-9

[26] Justnes, H., Østnor, T. A. "Alternative Binders Based on Lime and Calcined Clay", In: In: Scrivener, K., Favier, A. (eds.) Calcined Clays for Sustainable Concrete, Springer, Dordrecht, Netherlands, 2015, pp. 51-57.

https://doi.org/10.1007/978-94-017-9939-3

[27] Hu, X., Shia, Z., Shia, C., Wua, Z., Tonga, B., Ou, Z., de Schutter, G. "Drying shrinkage and cracking resistance of concrete made with ternary cementitious components", Construction and Building Materials, 149, pp. 406-415, 2017. https://doi.org/10.1016/j.conbuildmat.2017.05.113

[28] Rakhimova, N. R., Rakhimov, R. Z., Morozov, V. P., Gaifullin, A. R., Potapova, L. I., Gubaidullina, A. M., Osin, Y. N. "Marl-based geopolymers incorporated with limestone: A feasibility study", Journal of Non-Crystalline Solids, 492, pp. 1-10, 2018. https://doi.org/10.1016/j.jnoncrysol.2018.04.015

[29] CEN "EN 196-1 Methods of testing cement - Part 1: Determination of strength", European Committee for Standardization, Brussels, Belgium, 2016.

[30] TSE "TS 25 Natural pozzolan (Trass) for use in cement and concrete - Definitions, requirements and conformity criteria", Turkish Standard Institute, Ankara, Turkey, 2011.

[31] CEN "EN 197-1 Cement Part 1: Composition, specification and conformity criteria for common cements", European Committee for Standardization, Brussels, Belgium, 2012.

[32] CEN "EN 12620 Aggregates for concrete", European Committee for Standardization, Brussels, Belgium,2009.

[33] CEN "EN 934-2 Admixtures for concrete, mortar and grout - Part 2: Concrete admixtures; Definitions, requirements, conformity, marking and labelling", European Committee for Standardization, Brussels, Belgium, 2013.

[34] CEN "EN 196-6 Methods of testing cement - Part 6: Determination of fineness", European Committee for Standardization, Brussels, Belgium, 2010.

[35] CEN "EN 13791 Assessment of in-situ compressive strength in structures and precast concrete components", European Committee for Standardization, Brussels, Belgium, 2010. 
[36] Massazza, F. "Properties and applications of natural pozzolanas", In: Barnes, P., Bensted, J. (eds.) Structure and Performance of Cements, 2nd edition, Spon Press, London, UK, 2002, pp. 326-352. [online] Available at: http://refhub.elsevier.com/S09500618(16)30727-9/h0200

[37] Tironi, A., Trezza, M. A., Scian, A. N., Irassar, E. F. "Assessment of pozzolanic activity of different calcined clays", Cement and Concrete Composites, 37, pp. 319-327, 2013.

https://doi.org/10.1016/j.cemconcomp.2013.01.002

[38] CEN "EN 196-3 Methods of testing cement - Part 3: Determination of setting times and soundness", European Committee for Standardization, Brussels, Belgium, 2017.

[39] CEN "EN 12390-2 Testing hardened concrete - Part 2: Making and curing specimens for strength tests", European Committee for Standardization, Brussels, Belgium, 2010.

[40] ACI "ACI 211.1-91 Standard Practice for Selecting Proportions for Normal, Heavyweight, and Mass Concrete", American Concrete Institute, Farmington Hills, MI, USA, 2009.

[41] CEN "EN 12350-2 Testing fresh concrete - Part 2: Slump-test", European Committee for Standardization, Brussels, Belgium, 2010.

[42] CEN "EN 12390-3 Testing hardened concrete-Part 3: Compressive strength of test specimens", European Committee for Standardization, Brussels, Belgium, 2012.

[43] ISO "ISO 1920-8 Testing of concrete - Part 8: Determination of drying shrinkage of concrete for samples prepared in the field or in the laboratory", International Organization for Standardization, Geneva, Switzerland, 2009.

[44] Madlool, N. A., Saidur, R., Hossain, M. S., Rahim, N. A. "A critical review on energy use and savings in the cement industries", Renewable and Sustainable Energy Reviews, 15(4), pp. 2042-2060, 2011. https://doi.org/10.1016/j.rser.2011.01.005
[45] Labbaci, Y., Abdelaziz, Y., Mekkaoui, A., Alouani, A., Labbaci, B. "The use of the volcanic powders as supplementary cementitious materials for environmental-friendly durable concrete", Construction and Building Materials, 133, pp. 468-481, 2017. https://doi.org/10.1016/j.conbuildmat.2016.12.088

[46] Hamidi, M., Kacimi, L., Cyr, M., Clastres, P. "Evaluation and improvement of pozzolanic activity of andesite for its use in eco-efficient cement", Construction and Building Materials, 47, pp. 12681277, 2013. https://doi.org/10.1016/j.conbuildmat.2013.06.013

[47] Shon, C.-S., Kim, Y.-S. "Evaluation of West Texas natural zeolite as an alternative of ASTM Class F fly ash", Construction and Building Materials, 47, pp. 389-396, 2013. https://oi.org/10.1016/j.conbuildmat.2013.04.041

[48] Medjigbodo, G., Rozière, E., Charrier, K., Izoret, L., Loukili, A. "Hydration, shrinkage, and durability of ternary binders containing Portland cement, limestone filler and metakaolin", Construction and Building Materials, 183, pp. 114-126, 2018. https://doi.org/10.1016/j.conbuildmat.2018.06.138

[49] Wang, Y., Shui, Z., Sun, T., Huang, Y., Wang, G. "Effect of Fly Ash, Sinking Beads and Metakaolin on the Workability, Strength, Free Shrinkage and Chloride Resistance of Concretes: A Comparative Study", Arabian Journal for Science and Engineering, 43, pp. 5243$5254,2018$. https://doi.org/10.1007/s13369-018-3068-7

[50] Mihashi, H., de B. Leite, J. P. "State-of-the-Art Report on Control of Cracking in Early Age Concrete", Journal of Advanced Concrete Technology, 2(2), pp. 141-154, 2004.

https://doi.org/10.3151/jact.2.141 